\title{
The Robustness of Sectarian Politics in Lebanon: Reflections on the 2018 Elections Maguy Arnous
}

\begin{abstract}
Nine years after the last parliamentary elections, almost half of Lebanese voters cast their ballots on 6 May 2018, against expectations of a much higher turnout. The results of the elections marked a shift in the weight of coalitions among established political parties within a robust political system that is divided along sectarian lines, at the expense of new independent voices from civil society actors, that a proportional law should have advanced. This article attempts to analyse the results of the elections with regard to traditional parties, as well as the new so-called "civil society" candidates, while drawing inferences on the behaviour of the Lebanese voter.
\end{abstract}

Keywords: 2018 parliamentary elections, Lebanese Elections, Lebanese Politics

To cite this paper: Maguy Arnous, "The Robustness of Sectarian Politics in Lebanon: Reflections on the 2018 Elections ", Civil Society Knowledge Center, Lebanon Support, August, 2018 . DOI: 10.28943/CSKC.002.60000.

\section{[ONLINE]:}

https://civilsociety-centre.org/paper/robustness-sectarian-politics-lebanon-reflections-2018-elections

\section{Introduction}

In October 2017, a new election law was adopted in Lebanon, which for the first time included elements of proportional representation - leading political elites and local media to hail the elections as a celebratory day (“'irs intikh?bi") for the Lebanese people. Their enthusiasm, however, failed to translate into a similar sentiment amongst progressive political actors and candidates from "civil society," who believed the law created new electoral districts that would reproduce sectarianism. "The hastened adoption of the law, despite a laborious period of negotiations, obstructions and illegal extensions of parliamentary mandates, left some analysts with skeptical attitudes. As the date of the 2018 elections was fast approaching, they argued that the hybrid proportional law adopted would most likely bring the same MPs back to power.

Indeed, as the results of Lebanese elections - which took place on the 6 May 2018, after nine years of parliamentary mandate extensions ${ }^{[4]}$ - started rolling out, it became apparent that power sharing continued to be divided among long-lasting political parties at the expense of new independent voices that a proportional law would have advanced.

In this context, this article attempts to answer the following questions: How can we analyse the results of the elections for the established political parties? How can we interpret the results of "civil society" 
candidates? And what insights can we draw from the voting behaviour of the Lebanese electorate?

\section{A robust sectarian system}

Sectarianism is enshrined in the Lebanese political system. The core pillar of the Lebanese political system is consociational power sharing based on sectarian identities, which remains the key measure of political representation. Sectarian quotas are explicitly assigned for top government positions, and political parties and movements are directly associated with a specific sect whereby members would mostly belong to the same sect. ${ }^{[6]}$ More specifically, from independence in 1943 until now, the parliamentary electoral system remained a tool to institutionalise sectarianism and strengthen the sense of sectarian identity and solidarity. This institutionalisation of sectarianism has engendered consequences that gave rise to an almost impenetrable political system. According to Giovanni Sartori, the electoral system is "the most specific manipulative instrument of politics."

Similarly, since 1936, the Lebanese election system has been a majoritarian first-past-the-post system in multiple-member districts. Seats in each district are designated for candidates from particular sects, although all voters in each district can vote for any seat.

In addition to state policies, sectarianism was also perpetuated by non-state sectarian providers of social protection, which were omnipresent in Lebanon even before its independence. According to Cammett, when political organisations - at least those with sectarian affiliations - provide social services in countries such as India, Indonesia, Iraq, and Lebanon, they "constitute and reproduce the politics of sectarianism." For her, whenever states were unable to provide social protection to their citizens, the provision of social services by sectarian groups filled the gap and offered a sense of security to the most vulnerable groups.

Despite its flaws, the new electoral law allowed a coalition of civil society actors to campaign against established political parties in nine districts. During previous elections, the "winner-takes-all" law was the major barrier for mostly low-resource and decentralised civil society groups. The latter had nevertheless made significant gains in endorsing numerous advocacy campaigns, for example, women rights campaigns, ${ }^{[13]}$ and pushing for a new electoral law, as well as a reputation in winning in the municipality elections two years ago.

\section{A new electoral law: a significant change, or not?}

At first glance, the adoption of elements of proportional representation in the new electoral law appeared to be a move in the right direction for the country. Instead of the previous law with its relatively small districts (26), the new law allows electoral lists to win seats proportionally to the percentage of votes each acquires in 15 newly chartered districts. Thus, in theory, non-aligned actors and civil society actors had a bigger chance to reach supporters from different regions. However, the gerrymandering, the size of the districts, and the allotment of seats according to sectarian distributions in each, amongst others, worked against effective proportional representation, bringing back the old majoritarian system.

The introduced measures also included the restriction of preferential votes to the voter's caza 
of origin. ${ }^{[15]}$ For instance, even though Shouf and Aley were grouped under one electoral district Mount Lebanon IV during these elections, Shouf voters were unable to give their preferential votes to candidates running in Aley. Therefore, although some of the law's provisions were deemed as necessary reforms at first, the "political and sectarian calculus" used to delineate electoral districts shows that these provisions were deliberate to preserve status quo. The political discourse of major political parties, based on this calculus, correctly predicted that the elections would hold very few surprises, as areas of contention, often over one or two seats, were already determined.

\section{Elections day: a disputed turnout rate}

The delay in announcing the results, ${ }^{[18]}$ and the resignation of some members of the Supervision Committee, ${ }^{[19]}$ cast doubts on the process of a transparent election. The Ministry of Interior failed to post the final results of the elections until the following weekend. ${ }^{[20]}$ Overall, over 1.85 million voters cast their votes. Disaggregated data is still largely unavailable.

After a nine-year gap, a higher turnout could have been expected. The $49.2 \%$ turnout rate was lower than that of $2009(55 \%)$. $^{[21]}$ It can be argued that the newly adopted law was misunderstood by many, as corroborated by the large number of disqualified ballots (almost 39,000 ballots). ${ }^{[2]}$ While the results unfolded, the Lebanese people were unable to analyse the results and had to wait for an overdue announcement from the Minister of Interior. Indeed, Kamal Feghali, a renowned statistician and expert on Lebanese elections, reported that even those responsible for counting votes at polling stations ignored blank votes (over 15,000 in total), and votes for lists that did not specify a preferential vote.

While there has been a predominant buzz after the elections on low turnout rate, this is nuanced by some experts. Associate Professor of Political Science at the Lebanese American University, Dr. Imad Salamey explains: "This election did not have a low turnout. Approximately $15 \%$ of registered voters reside abroad. It means turnout was actually about $65 \%$ which is high by international standards." ${ }^{[24]}$ However, the debate over the turnout rate does not revolve solely on the high or low designations. Mohammad Zbeeb of al-Akhbar puts into question the validity of the number of votes announced by the Ministry of Interior. He argues that with a lack of a national census, ${ }^{[25]}$ the numbers coming out from the elections, regarding the turnout rate and the total number of voters, must be taken with a grain of salt. Numbers from different experts and polling companies show significant discrepancies. ${ }^{[2]}$ One such company reports that the number of eligible voters in Lebanon is 2.2 million, making the turnout rate close to $85 \%$.

Nevertheless, comparing turnout rates among districts exhibits a particularly low turnout rate in Beirut I and II districts, with $33.13 \%$ and $41.25 \%$, respectively, making them the lowest across all districts, with South I and Keserwan districts being the highest with $56.2 \%$ and $53.1 \%$, respectively.

As the Minister of Interior Nuhad al-Machnuq was proclaiming the operational success of election day, the Lebanese Association for Democratic Election (LADE), which monitored the elections, reported over 7000 violations across all electoral districts. ${ }^{[2]]}$ For example, LADE reported 242 voting centers were not equipped to accommodate voters with special needs. ${ }^{[30]}$ Local TV stations, social media activists, and non-governmental organisations also recorded several violations, among which were vote buying, intimidation of voters by party and candidate delegates, and sectarian violence between supporters of 
different coalitions. $^{[31]}$ Lebanon Support mapped more than 25 violent incidents during and after election day, including clashes between rival political parties and celebratory shootings, ${ }^{[32]}$ raising questions over the possibility of relapse into yet another cycle of violence in Lebanon. ${ }^{[33]}$ Scenes of street violence between the supporters of multiple opposing factions are not foreign on the Lebanese streets, especially in its capital Beirut. Oftentimes, such incidents require the immediate intervention of the Lebanese army. Military tanks rolling on the streets to restore order, as well as direct instructions to pull out of the streets from political leaders (za'im) usually end these sporadic clashes.

\section{New measures, new voter behaviour? A shift in the weight of coalitions}

While these elections continued to maintain the robustness of the system, it resulted in shift in the weight of coalitions among established sectarian parties. The Free Patriotic Movement (FPM) secured the largest bloc with 29 representatives. The 14 seats won by the Amal movement, along with Hezbollah's (13), constitute a lockdown on the entire Shia' seats in parliament. Along with their allies, and Hezbollah's strategic alliance with FPM, the so-called Syrian affiliated March 8 coalition won an overwhelming majority in parliament.

Compared to 2009, the majority in parliament shifted from political groups affiliated to the March 14 bloc to those closer to March 8 bloc. ${ }^{[35]}$ This is significant as the majority in parliament affects, amongst other things, cabinet formation, Lebanon's regional alliances and foreign policy behaviour, and its stance towards conflicts in the region. As coalitions and political alliances stand at the moment, Hezbollah seems to be in a better position than in the past nine years. Hezbollah's MPs and its allies currently amount to 80 seats in the Parliament. ${ }^{[36]}$ This is particularly significant when regional developments, including Iran's nuclear deal, and the confrontation between Israel and Iran are rapidly emerging.

Political parties, formerly affiliated with March 14 coalition, had mixed results. ${ }^{[37]}$ While the Progressive Socialist Party (PSP) still managed to win nine seats, and the Lebanese Forces (LF) increased their representation from eight to $15 \mathrm{MPs}$, the Future Movement and the Phalange party suffered heavy losses in numbers of seats. The PSP won six out of seven seats allocated for the Druze community. The seventh seat went to the leader of Lebanese Democratic Party Talal Arslan. The Phalange party got three seats, while Sa'ad al-Hariri's party went down from 34 representatives to only $19 .^{[38}$

Indeed Sa'ad al-Hariri received a higher number of preferential votes compared to all other lists, but that failed to materialise into a strong win for his list. ${ }^{[39]}$ After a difficult year for Hariri, following his resignation, announced from Saudi Arabia, in November of last year, which he revoked as soon as he came back to Lebanon, winning less than expected in Beirut led to an immediate internal questioning of organisational and political strategies during his campaign and well before that. ${ }^{401}$ In fact, a week after the elections, it appears that Hariri was already re-shuffling his cards, as some of his top party members either resigned or were dismissed.

Despite losing several seats in parliament, specifically in Beirut II district, the Future Movement remains the main Sunni representative, and Hariri the leader of the next government. While the Future Movement's representation in Parliament suffered, analysts maintained that this might not be definitely linked to their popularity on the ground, but is rather due to the proportional nature of the new law. "The new electoral system is largely to blame for the losses. In terms of support and popularity, not much 
has changed since the last election. Hariri's public support is of national orientation, with many nonSunni voters unable to cast their votes in his favour. The results expressed political diversity among the Sunnis, who may now find the electoral system to have produced representatives through non-Sunni votes. A traditional grievance held by Christians," Salamey says. However, it seems that despite a little over a decade of unwavering support to Sa?ad al-Hariri, the Sunni community might be re-orienting itself to a pre-2005 period, distributing its votes across several Sunni leaderships.

The robust representation of traditional sectarian parties can be explained by the Lebanese consociational system that predetermines power sharing along sectarian divides. Ever since the Tai?f agreement, Christian political parties have been trying to get out of al-ihb?t al-mas?h? (the Christian disenchantment), arguing that the accord enabled Muslim voters to choose Christian representatives. The Christian community, spearheaded by the FPM and the LF, opposing the majoritarian law, supported the highly debated Orthodox law a few years ago, which stipulated that voters only elect MPs that belong to their sect. ${ }^{[43]}$ The law was advanced to allow Christians to elect their representatives. Despite heavy criticism, part of the Orthodox law still finds itself in the current law with the preferential vote clause. "Candidates sought preferential votes from their co-confessionalists, leading to the electoral system operating similarly to the 'Orthodox law," Sami Atallah, Lebanese Center for Policy Studies executive director, wrote in a recent article.

\section{The struggle of "civil society" candidates}

In discussing grievances, it seems obvious to question sectarian ones but also those held by secular and independent parties or coalitions. Independent, secular, and organised political parties who are not aligned with major parties were once again overshadowed during these elections. Nevertheless, the coalition Kulluna Watani, which encompassed 66 candidates across nine districts, reignited a glimmer of hope for change, as it was the first time so-called independent candidates aligned under civil society coalitions. Activists and representatives of Kulluna Watani maintained that they ran a successful campaign, while acknowledging the continuity of the struggle against the sectarian system and political elites, and advancing creative strategies to ameliorate the fight and prepare for further confrontations.

In Beirut I district, ${ }^{[46]}$ where candidate Paula Yaacoubian running on Kulluna Watani's list was able to secure a seat, traditional political parties seemed to have underestimated the coalition's as well as other independent candidates' momentum. Contrary to previous elections, including this one, the district could have presented itself as an area of contention if "civil society" actors coalesced further efforts in attracting new voters. This is specially true since a second seat was almost won by Joumana Haddad, and most members of the Kulluna Watani list received significant numbers of preferential votes $(6,842$ votes). However, despite the singular seat, Yaacoubian's win is largely due to the Armenian constituency in Beirut I, mirroring affiliated voters' sectarian behaviour. "In her case, Armenian Orthodox voters helped her victory. Not sure how much we can interpret this as a civil society victory," Salamey commented.

The loss of "civil society" actors and alternative voices, despite obvious frustrations, was surprising. During an interview with an independent candidate running in the South, Jeroen Gunning, ${ }^{[49]}$ Professor of Middle Eastern Politics and Conflict Studies at King's College (London), reported that as long as voters need to go back to their villages to vote, independents will always be on the back foot. 
"Whenever a party is in the majority in a particular area, they dominated the scene visually and orally," Gunning stated. ${ }^{[5]}$ From his preliminary observations, people who wanted to vote against the party with the largest constituency in a particular region were feeling intimidated and uncomfortable to express whom they wanted to, or had voted for. Therefore, it can be argued that new measures in the electoral law - later omitted, such as magnetic voting cards and big voting centers where voters could cast their votes in their areas of residence - stood against increasing the turnout rate and impacted the chances of "civil society" candidates.

Moreover, the election of wealthy businessmen (such as Fouad al-Makhzoumi in Beirut) can indicate that people are more willing to vote for candidates perceived to be able to deliver immediate returns (i.e. protection, services, and jobs, etc.). This electoral behaviour validates preliminary data gathered through focus groups conducted by Lebanon Support ${ }^{[511}$ a week before the elections. Also, voters were more willing to vote for a candidate who belongs to the same sect/religion rather than an independent candidate. ${ }^{[2]}$ Besides sectarianism, "the electoral system is still built around clientelism. Because of that, you almost need to become a patron before running for elections," Gunning said, ${ }^{[53]}$ addressing the challenges of "civil society" candidates, who oppose clientelism. ${ }^{[54]}$ Providing services and a perception of a shared identity (unrelated to class) are the main tools employed by the political class, and are therefore the main obstacles for "civil society" actors and independent coalitions to break the entrenched patron-client relationship witnessed in Lebanon between candidate and voter. Gunning's argument resonates with Cammett's: the Lebanese voter perceives, and therefore reinforces, belonging to a sect and affiliating with sectarian political parties and leaders will result in sustainable returns and immediate benefits during and post-election. ${ }^{[5]}$ Since the discourse of candidates emerging from "civil society" revolves around an anti-system rhetoric ("killon ya'ane killon"), voters perceived independent candidates as unable to deliver on campaign promises.

\section{Looking Ahead}

Two months after the long-awaited parliamentary elections, a new government has still not seen the light. Cabinet formation is a hurdle that is proving to be difficult to overcome. The tacit agreement between the three powers governing the country (presidential, legislative, and executive) that brought about the election of a new president after a long hiatus, and the adoption of a new electoral law, is now unable to overcome disagreements to form a new government. ${ }^{[5]}$ This is especially true when the political alignments and coalitions during the elections soon broke apart. Major decisions await the new government, the least of which are the urgent discussions around the Syrian refugees' crisis and the consequences of the international conference in support of Lebanon development and reforms (CEDRE). ${ }^{[57]}$ The delay in forming a cabinet, a new trend in Lebanon for the past decade, is a tangible proof that little has changed after the last elections. As the Lebanese people hold their breaths for a new government, what it might actually accomplish remains to be seen.

Despite celebratory claims of democratic elections, Lebanon still lacks the prerequisites for democracy, as sectarian politics in Lebanon reproduce the same robust and almost impenetrable political class. According to Edmond Rabbath, writing in 1982, the so-called "Lebanese democracy" was not a democracy in the real sense of the term. Its core principle, organisation, and function were based on sectarian and institutionalised discrimination. It was, therefore, a democracy of a sectarian composition whose direct subjects were not citizens, rather communities. This distorted form of democracy would 
only lead to inequalities.

For "civil society" actors, an introspective look is needed. Candidates must move beyond mere orbits that hover around and react to an established political class in order to sway voters in their favour. While political sectarianism cannot be surpassed in one electoral campaign, playing the Lebanese "political game" might not necessarily mean a betrayal of values, but an attempt at bridging the gap between what is ideal and what is feasible, and between short-term gains and long-term goals. Lastly, there a need for a post-election assessment of organisational and political strategies, whereas electoral alliances ought to be closely examined. As Eva Bellin once noted, "to anchor democracy [...], political reformers must focus on building effective, impartial state institutions, nurturing associations that reach across ethnic lines and unite people around common economic and cultural interests."

*The title is inspired from: Eva Bellin, "The Robustness of Authoritarianism in the Middle East: Exceptionalism in Comparative Perspective," Comparative Politics, Vol. 36 (2), 2004, p. 139-157, available at: https://scholar.harvard.edu/files/levitsky/files/bellin.pdf [last accessed 24 May 2018].

"1] “Is Lebanon's New Electoral System a Path Out of Sectarianism?", Website, The New Yorker, 29 June 2017, available at:

https://www.newyorker.com/news/news-desk/is-lebanons-new-electoral-syste... [last accessed 20 July 2018].

[2] Sami Atallah and Zeina el-Helou, "“'Our” New Electoral Law: Proportional in Form, Majoritarian at Heart," Website, Lebanese Center for Policy Studies, June 2017, available on: https://www.Icpslebanon.org/featuredArticle.php?id=117 [last access 24 May 2018].

[d] $I$ em.

[4] The Lebanese parliament renewed its mandate three times (in 2013, 2014 and 2017) due to political obstructions and inability to agree on an electoral law. Civil society actors mobilised against the extensions. For more on the Civil Movement for Accountability and their mobilisation, see Lebanon Support, "Civil Movement for Accountiblity," Website, Civil Society Knowledge Centre, 11 May 2015, available at: https://civilsociety-centre.org/party/civil-movement-accountability [last accessed 8 June 2018]. 
[5] The constitutional amendments introduced by the Tai?f agreement that formally ended the Lebanese Civil War (1975-1990) included the guiding principle for the distribution of parliamentary seats equally between Christians and Muslims, and proportionally among the different sects within each community (article 24).

${ }^{[6]}$ Lea Bou Khater, Labour Relations in Lebanon: Trials and Tribulations of the Labour Movement, PhD Dissertation, University of London, School of Oriental and African Studies, 2016, p. 64.

Edmond Rabbath, La Constitution Libanaise: origines, textes et commentaires, Beirut, Publications de l'Université Libanaise, 1982, p. 5.

${ }^{[8]}$ Larry Diamond and Marc Plattner, Electoral Systems and Democracy, Baltimore, John Hopkins University Press, 2006, p. 74.

[9] The old majoritarian electoral law adopted a "winner takes all" rule, where in a given district any list that gets more than $50 \%$ of the votes wins all the seats allocated to that district.

${ }^{[10]}$ Lea Bou Khater, op.cit., 2016, p. 76. 
[11] Melani Cammett, Compassionate Communalism: Welfare and Sectarianism in Lebanon, Ithaca, Cornell University Press, 2014, p. 7-8.

Idem.

[13] "Women's rights organizations campaign against gender-based violence," The Daily Star, 1 December 2016, available at: http://www.dailystar.com.Ib/News/Lebanon-

News/2016/Dec-01/383611-womens-... [last accessed 25 July 2018].

[14] "A challenge to the stinkers: Beirut shocks its old guard," The Economist, 11 May 2016, available at: https://www.economist.com/middle-east-and-africa/2016/05/11/beirut-shocks-its-old-guard [last accessed 25 July 2018].

[15] "Lebanese electoral law 2017: Full text in English," The Daily Star, 5 May 2018, available at:

http://www.dailystar.com.lb/News/Lebanon-News/2017/Jul-07/411988-lebanes... [last accessed 15 July 2018].

${ }^{[16]}$ Melani Cammett, op.cit., 2014, p. 7-8.

[17] Asma Ajroudi, "Will the Lebanese vote in parliamentary elections?", Website, al-Jazeera, 23 April 2018, available at: https://www. aljazeera.com/news/2018/04/lebanese-vote-parliamentary-elect... [last 
accessed 24 May 2018].

[18] "Lebanon still waiting for official election results," The Daily Star, 7 May 2018, available at:

http://www.dailystar.com.lb/News/Lebanon-Elections/2018/May-07/448342-le... [last accessed 24 May 2018].

${ }^{[19]}$ "Electoral Supervisory Committee member resigns," The Daily Star, 20 April 2018, available at: http://www.dailystar.com.lb/News/Lebanon-News/2018/Apr-20/446055-elector... [last accessed 24 May 2018].

[20] "2018 Election Results," Website, Ministry of Interior, 2018, available at: https://goo.gl/mhZYJu [last accessed 24 May 2018].

[21] Idem.

Idem; Official numbers of disqualified ballots from previous elections are not available.

Kamal Feghali, "???? ????? ?? ???? ????????!," al-Akhbar Newspaper, 11 May 2018, available at: https://goo.gl/iMLDfV [last accessed 24 May 2018]. 
${ }^{[24]}$ Interview by the author with Associate Professor of Political Science at the Lebanese American University Dr. Imad Salamey, by email, 11 May 2018.

${ }^{[25]}$ The last census of Lebanon was conducted in 1932.

${ }^{[26]}$ Electoral lists accounted for almost three million six hundred thousand Lebanese residing in Lebanon. A polling company, however, found that the number of eligible voters above 21 was nearly two million one hundred sixty thousand, less than one million five hundred thousand voters than the first number.

[27] This estimation factors in the number of Lebanese immigrants and those residing abroad. See Mohammad Zbeeb, "???? ?? ???? ??????? al-Akhbar Newspaper, 14 May 2018, available at: https://goo.gl/oRZwmy [last accessed 24 May 2018].

[28] "Final breakdown of voter turnout for 2018 elections," The Daily Star, 7 May 2018, available at: http://www.dailystar.com.Ib/News/Lebanon-Elections/2018/May-07/448314-fi... [last accessed 24 May 2018].

LA29] LAE, "????? ??????? ?????? ?????? ??? ???????? Beirut, LADE, 2018, p. 7 available at: https://goo.gl/qWytCD [last accessed 24 May 2018]. 
[30] Idem.

[31] Idem.

[32] Lebanon Support, "\#HighConflictivitySignal," Facebook post, 10 May 2018, available at: https://www.facebook.com/LebanonSupport/posts/1850051698360198 [last accessed 17 May 2018].

${ }^{[33]}$ Lebanon Support, "\#HighConflictivitySignal," Facebook post, 10 May 2018, available at: https://www.facebook.com/LebanonSupport/posts/1850051698360198 [last accessed 17 May 2018].

${ }^{344}$ Tom Perry and Laila Bassam, "Old enmity tips Lebanon into new crisis," Reuters, 29 January 2018, available at: https://www.reuters.com/article/us-lebanon-politics/old-enmity-tips-lebanon-into-new-crisisidUSKBN1FI29Q [last accessed 26 July 2018].

${ }^{[35]}$ Richard Chambers, "Lebanon's 7 June Elections: The Results," Lebanon, International Foundation for Electoral Systems, 2009, p.2, 4, available at: https://recef.org/wp-content/plugins/cptbibliotheque/telecharger.php?id... [last accessed 15 July 2018].

${ }^{[36]}$ Ministry of Interior, op.cit., 2018. 
${ }^{[37]}$ Even though March 8 and March 14 camps have become obsolete, the designation is used here to differentiate between two opposing political agendas for the political orientation and regional alliances of the country.

Ministry of Interior, op.cit., 2018.

${ }^{[39]}$ Each list needs to first gather enough votes to reach the threshold of votes of a given district. If it does, it wins a number of seats in the district proportional to the percentage of votes it got. Preferential votes determine the candidates who win those seats. With the highest number of preferential votes for Hariri, he won one Sunni seat in Beirut II, but his list won six seats out of 11 , which is considered a setback for Hariri and his party.

${ }^{[40]}$ Dexter Filkins, "A Saudi Prince's Quest to Remake the Middle East," Website, The New Yorker, 9 April 2018, available at: https://www.newyorker.com/magazine/2018/04/09/a-saudi-princes-quest-to-r... [last accessed 24 May 2018].

${ }^{[411]}$ Interview by the author with Associate Professor of Political Science at the Lebanese American University Dr. Imad Salamey, by email, 11 May 2018.

${ }^{[42]}$ Since the assassination of late PM Rafic al-Hariri, the Future Party, headed by his son Sa'ad alHariri has witnessed unprecedented landslide victories, along its allies in the 14 March bloc. 
${ }^{[43]}$ Matt Nash, "How to have a fair election: Parliament is weighing different proposals," Executive Magazine, 8 February 2017, available at: http://www.executive-magazine.com/economics-policy/how-tohave-a-fair-el... [last accessed 20 July 2018].

[44] Sami Atallah, "To be Successful, Proportional Representation must be Accompanied by Party Reform," Website, Lebanese Center for Policy Studies, May 2018, available on: https://www.lcpslebanon.org/featuredArticle.php?id=155 [last access 24 May 2018]

${ }^{[45]}$ Nizar Hassan, "Lebanon's 2015 Protest Movement: An Analysis of Class (and) Power," MA thesis, University of London, School of Oriental and African Studies, 2017, available at:

https://www.researchgate.net/publication/319902826_Lebanon

's_2015_Protest_Movement_An_analysis_of_class_and_power [last accessed 24 May 2018].

${ }^{[46]}$ Beirut I district groups four regions together: Ashrafieh, Rmeil, Mdawar, and Saifi.

[47] Ministry of Interior, op.cit., 2018.

${ }^{[48]}$ Interview by the author with Associate Professor of Political Science at the Lebanese American University Dr. Imad Salamey, by email, 11 May 2018. 


\section{Civil Society Knowledge

[49] Interview by the author with Professor of Middle Eastern Politics and Conflict Studies at King's College (London) Dr. Jeroen Gunning, Beirut, 13 May 2018.

${ }^{[50]} / d e m$.

${ }^{[51]}$ Zeina el-Helou, Pre- and post Elections qualitative public opinion research, The Civil Society Knowledge Centre, forthcoming, 2018.

I52] $I d e m$.

${ }^{[53]}$ Interview by the author with Professor of Middle Eastern Politics and Conflict Studies at King's College (London) Dr. Jeroen Gunning, 2018.

${ }^{[54]}$ Nada Ayoub, “"???? ????": 66 ????? ?? 9 ????? ????? ???? ???????? ??? ??????????," An-Nahar Newspaper, 9 April 2018, available at: https://goo.gl/cLHW3r [last accessed 24 May 2018].

${ }^{[55]}$ Melani Cammett, op.cit., 2014, p. 7-8. 
[56] Hussein Dakroub, "Lebanon set for long delay in Cabinet formation," The Daily Star, 7 July 2018, available at:

http://www.dailystar.com.Ib/News/Lebanon-News/2018/Jul-07/455691-lebanon-set-for-long-delay-incabinet-formation.ashx [last accessed 7 August 2018].

[57] In French, it is Conférence économique pour le développement, par les réformes et avec les entreprises. The objective of the CEDRE conference was "for the international community to support the development and the strengthening of the Lebanese economy as part of a comprehensive plan for reform and for infrastructure investments as prepared by the Lebanese authorities and presented during the conference." See: "Lebanon - CEDRE Conference," Website, France Diplomatie, 2018, available at:

https://www.diplomatie.gouv.fr/en/country-files/lebanon/events/article/lebanon-cedreconference-06-04-18 [last accessed 26 July 2018]

${ }^{[58]}$ Edmond Rabbath, op.cit., 1982, p.135, 137.

${ }^{[59]}$ Eva Bellin, op.cit., 2004, p. 153. 